\title{
The $\mathrm{Na}^{+}$-dependent chloride-bicarbonate exchanger SLC4A8 mediates an electroneutral $\mathrm{Na}^{+}$reabsorption process in the renal cortical collecting ducts of mice
}

\author{
Françoise Leviel,1,2,3 Christian A. Hübner,4,5 Pascal Houillier, ${ }^{1,2,3}$ Luciana Morla,1 \\ Soumaya El Moghrabi, ${ }^{1}$ Gaëlle Brideau, ${ }^{1}$ Hassan Hatim, ${ }^{6}$ Mark D. Parker, ${ }^{7}$ Ingo Kurth, ${ }^{5}$ \\ Alexandra Kougioumtzes, ${ }^{5}$ Anne Sinning, ${ }^{4}$ Vladimir Pech, ${ }^{8}$ Kent A. Riemondy, ${ }^{9}$ R. Lance Miller, ${ }^{9}$ \\ Edith Hummler, ${ }^{10}$ Gary E. Shull, ${ }^{11}$ Peter S. Aronson, ${ }^{6}$ Alain Doucet, ${ }^{1}$ Susan M. Wall, ${ }^{8}$
} Régine Chambrey, ${ }^{1}$ and Dominique Eladari1,2,3

\begin{abstract}
${ }^{1}$ Centre de recherche des Cordeliers, Université Pierre et Marie Curie, ERL CNRS 7226, INSERM UMRS 872 (Equipe 3), Paris, France. 2Département de Physiologie, HEGP-Necker-Enfants Malades, AP-HP, Paris, France. ${ }^{3}$ Faculté de Médecine Paris Descartes, Université Paris Descartes, Paris, France. ${ }^{4}$ Institute for Clinical Chemistry, University Hospital Jena, Friedrich Schiller Universität, Jena, Germany. ${ }^{5}$ Department of Human Genetics, Universitätsklinikum Hamburg-Eppendorf, Hamburg, Germany. ${ }^{6}$ Yale University School of Medicine, Department of Internal Medicine, Section of Nephrology, New Haven, Connecticut, USA. ${ }^{7}$ Case Western Reserve University School of Medicine, Cleveland, Ohio, USA. ${ }^{8}$ Emory University School of Medicine, Department of Medicine, Renal Division, Atlanta, Georgia, USA. ${ }^{9}$ Department of Pediatrics, Division of Nephrology, University of Utah, Salt Lake City, Utah, USA. ${ }^{10}$ Université de Lausanne, Département de Pharmacologie et de Toxicologie, Lausanne, Switzerland. ${ }^{11 U n i v e r s i t y ~ o f ~ C i n c i n n a t i, ~}$
\end{abstract} Department of Molecular Genetics, Cincinnati, Ohio, USA.

\begin{abstract}
Regulation of sodium balance is a critical factor in the maintenance of euvolemia, and dysregulation of renal sodium excretion results in disorders of altered intravascular volume, such as hypertension. The amiloridesensitive epithelial sodium channel $(\mathrm{ENaC})$ is thought to be the only mechanism for sodium transport in the cortical collecting duct (CCD) of the kidney. However, it has been found that much of the sodium absorption in the CCD is actually amiloride insensitive and sensitive to thiazide diuretics, which also block the $\mathrm{Na}-\mathrm{Cl}$ cotransporter (NCC) located in the distal convoluted tubule. In this study, we have demonstrated the presence of electroneutral, amiloride-resistant, thiazide-sensitive, transepithelial $\mathrm{NaCl}$ absorption in mouse CCDs, which persists even with genetic disruption of ENaC. Furthermore, hydrochlorothiazide (HCTZ) increased excretion of $\mathrm{Na}^{+}$and $\mathrm{Cl}^{-}$in mice devoid of the thiazide target NCC, suggesting that an additional mechanism might account for this effect. Studies on isolated CCDs suggested that the parallel action of the $\mathrm{Na}^{+}$-driven $\mathrm{Cl}^{-} / \mathrm{HCO}_{3}{ }^{-}$exchanger (NDCBE/SLC4A8) and the $\mathrm{Na}^{+}$-independent $\mathrm{Cl}^{-} / \mathrm{HCO}_{3}{ }^{-}$exchanger (pendrin/SLC26A4) accounted for the electroneutral thiazide-sensitive sodium transport. Furthermore, genetic ablation of SLC4A8 abolished thiazide-sensitive $\mathrm{NaCl}$ transport in the $\mathrm{CCD}$. These studies establish what we believe to be a novel role for $\mathrm{NDCBE}$ in mediating substantial $\mathrm{Na}^{+}$reabsorption in the CCD and suggest a role for this transporter in the regulation of fluid homeostasis in mice.
\end{abstract}

\section{Introduction}

Sodium chloride is the main extracellular osmotic constituent and thereby determines extracellular volume and blood pressure. To maintain a constant extracellular volume, the kidney has to match sodium excretion to dietary sodium intake. Abnormal retention of sodium by the kidney can ultimately lead to expansion of the extracellular volume and hypertension (1), the most common pathological state in humans. Since sodium is freely filtered by the glomerulus, most of it has to be reabsorbed as the filtrate flows along the nephron. This reabsorption is mediated by the $\mathrm{Na}^{+} / \mathrm{H}^{+}$ exchanger NHE3 in the proximal tubule (2), by the $\mathrm{Na}^{+} / \mathrm{K}^{+} / 2 \mathrm{Cl}^{-}$ cotransporter NKCC2 in the thick ascending limb of Henle's loop (3), and by the $\mathrm{NaCl}$ cotransporter NCC in the distal convoluted tubule (DCT) $(3,4)$. Finally, the remaining fraction of filtered sodi-

Authorship note: Françoise Leviel and Christian A. Hübner share first authorship. Pascal Houillier and Luciana Morla contributed equally to this work.

Conflict of interest: The authors have declared that no conflict of interest exists. Citation for this article: J Clin Invest. 2010;120(5):1627-1635. doi:10.1172/JCI40145 um enters the connecting tubule and the collecting duct. In these latter segments, aldosterone increases distal sodium reabsorption via the $\mathrm{Na}^{+}$channel $\mathrm{ENaC}$ (5). Supporting the importance of renal $\mathrm{Na}^{+}$handling in blood pressure regulation, inactivating mutations in the genes that code for renal sodium transporters are associated with low blood pressure (6-10), whereas inherited and acquired forms of hypertension can result from increased renal sodium reabsorption (11).

Drugs that selectively block the different aforementioned renal sodium transporters are the pharmacological basis of treatment of disease states characterized by abnormal renal sodium retention, such as edematous disorders and hypertension. Although discovered half a century ago (12), thiazides have been the cornerstone of therapy for mild and moderate hypertension in nearly all prospective therapeutic trials to date (13). Their efficacy in preventing hypertensive cardiovascular complications such as stroke and congestive heart failure has been verified in large clinical trials (14). Thiazides are believed to act exclusively by blocking sodium absorption via NCC, which represents only approximately $5 \%$ 

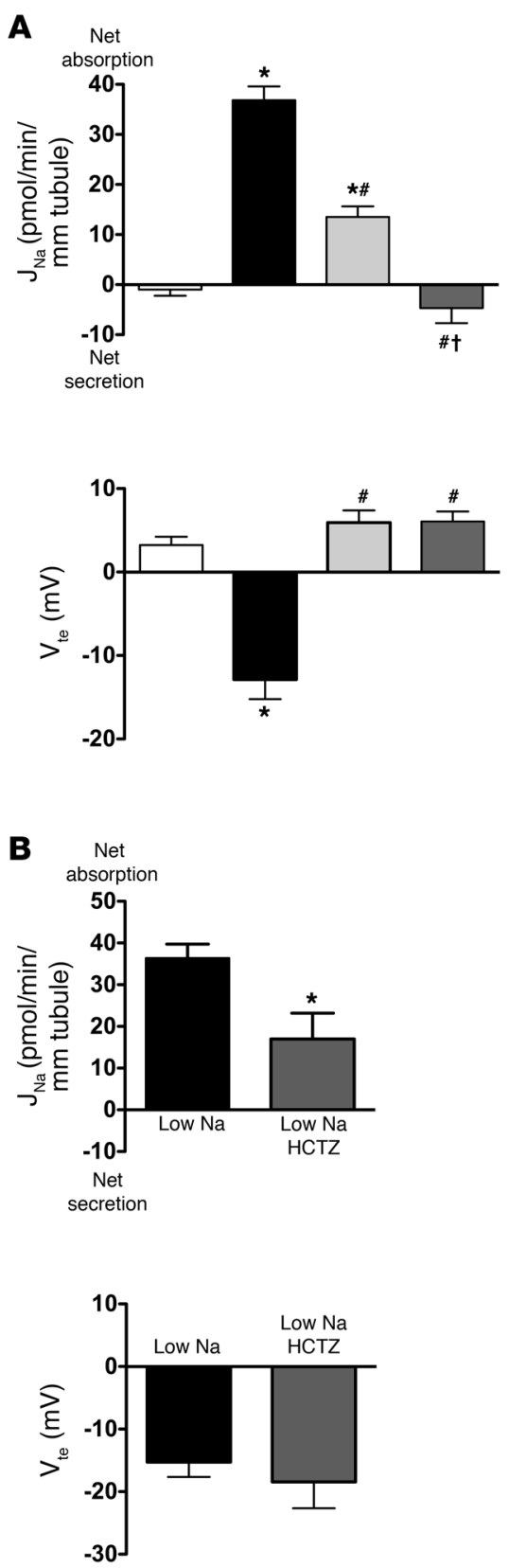
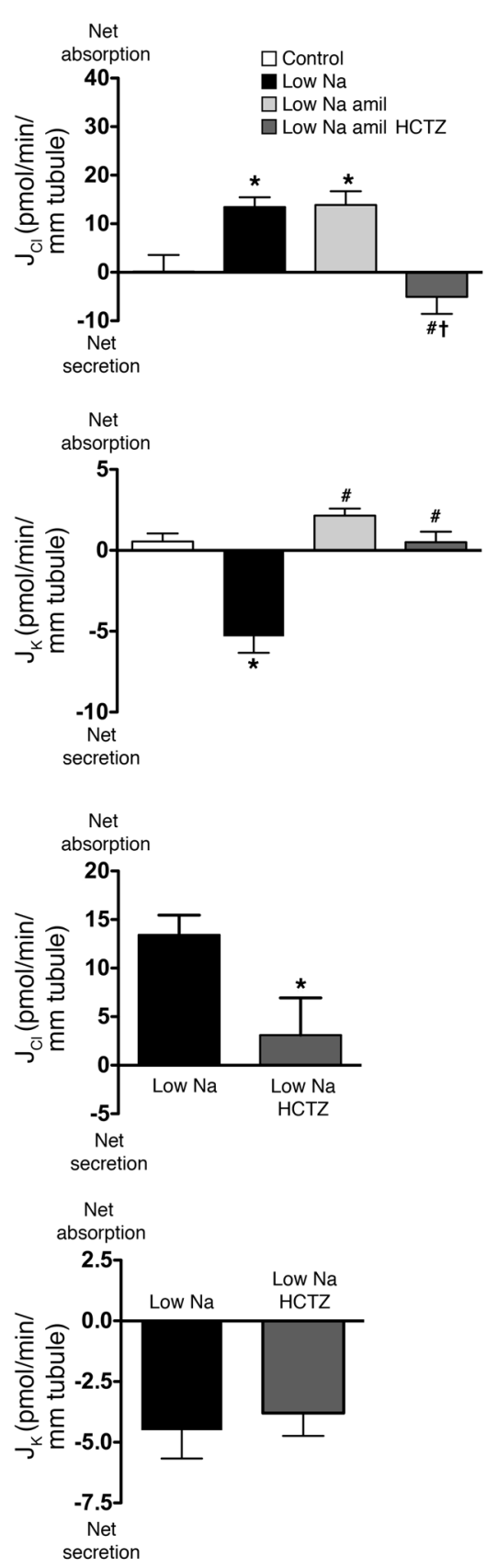

\section{Figure 1}

Pharmacological characterization of transepithelial transport of $\mathrm{Na}^{+}, \mathrm{K}^{+}$, and $\mathrm{Cl}^{-}$in collecting ducts isolated from wild-type mice. (A) Effects of amiloride $\left(10^{-5} \mathrm{M}\right)$ and $\mathrm{HCTZ}\left(10^{-4} \mathrm{M}\right)$ on $\mathrm{Na}^{+}$, $\mathrm{Cl}^{-}$, and $\mathrm{K}^{+}$transepithelial fluxes and on transepithelial voltage in CCDs isolated from $\mathrm{Na}^{+}-$ restricted mice. $\mathrm{J}_{\mathrm{Na}}$, rate of $\mathrm{Na}^{+}$absorption; $\mathrm{J}_{\mathrm{Cl}}$, rate of $\mathrm{Cl}^{-}$absorption; $\mathrm{V}_{\text {te }}$, transepithelial voltage; $\mathrm{J}_{\mathrm{K}}$, rate of $\mathrm{K}^{+}$secretion. Statistical significance was assessed by ANOVA; comparisons between groups were tested by Bonferroni's post-hoc test. $n=5$ in each group, ${ }^{*} P<0.05$ versus control, ${ }^{\#} P<0.05$ versus low $\mathrm{Na}^{+} ;{ }^{\dagger} P<0.05$ versus low $\mathrm{Na}^{+}$amiloride (amil). (B) Effects of HCTZ alone $\left(10^{-4} \mathrm{M}\right)$ on $\mathrm{Na}^{+}, \mathrm{Cl}^{-}$, and $\mathrm{K}^{+}$transepithelial fluxes and on transepithelial voltage in CCDs isolated from $\mathrm{Na}^{+}$-restricted mice. Statistical significance was assessed by 2-tailed unpaired Student's $t$ test. $n=5$ in each group; ${ }^{*} P<0.05$ versus control (low $\mathrm{Na}$ ).

for the treatment of arterial hypertension and our understanding of the role of the CCD in the regulation of $\mathrm{Na}^{+}$and $\mathrm{K}^{+}$homeostasis.

\section{Results}

Electrogenic and electroneutral $\mathrm{Na}^{+}$absorption pathways coexist in the mouse collecting duct. To verify the presence of the previously reported thiazide-sensitive component of $\mathrm{Na}^{+}$absorption, we simultaneously measured transepithelial $\mathrm{Na}^{+}\left(\mathrm{J}_{\mathrm{Na}}\right), \mathrm{K}^{+}\left(\mathrm{J}_{\mathrm{K}}\right)$, and $\mathrm{Cl}^{-}\left(\mathrm{J}_{\mathrm{Cl}}\right)$ fluxes and transepithelial voltage $\left(\mathrm{V}_{\mathrm{te}}\right)$ in isolated mouse CCDs microperfused in vitro. Because mouse CCDs do not absorb $\mathrm{NaCl}$ under basal conditions (see ref. 20 and control group in Figure 1A), we stimulated $\mathrm{NaCl}$ absorption by feeding the mice a $\mathrm{Na}^{+}$-depleted diet for 2 weeks before the experiments. CCDs from $\mathrm{NaCl}$-restricted wildtype mice absorbed $\mathrm{Na}^{+}$and $\mathrm{Cl}^{-}$, secreted $\mathrm{K}^{+}$, and generated a lumen-negative transepithelial voltage $\left(\mathrm{V}_{\mathrm{te}}\right)$, consistent with $\mathrm{ENaC}$-mediated $\mathrm{Na}^{+}$absorption (Figure 1A). Amiloride in the perfusate, at concentrations that fully inhibit $\mathrm{ENaC}\left(10^{-5} \mathrm{M}\right)(21)$, did not change $\mathrm{Cl}^{-}$ absorption (Figure $1 \mathrm{~A}$ ), although both $\mathrm{V}_{\text {te }}$ and $\mathrm{K}^{+}$secretion were eliminated and $\mathrm{Na}^{+}$absorp-

of the total amount of $\mathrm{Na}^{+}$filtered by the glomerulus $(15,16)$. However, previous studies have shown that approximately $50 \%$ of $\mathrm{Na}^{+}$absorption in the rat collecting duct is thiazide sensitive and amiloride insensitive (17-19), even though the expression of its canonical target, NCC, is restricted to the DCT.

Given its clinical relevance, we aimed to identify the transport system that accounts for this amiloride-insensitive, thiazide-sensitive $\mathrm{Na}^{+}$absorption in the cortical collecting duct (CCD). With a combined functional and genetic approach, we show that the parallel action of the $\mathrm{Na}^{+}$-independent anion exchanger pendrin/ $\mathrm{Pds} / \mathrm{SLC} 26 \mathrm{~A} 4$ and the $\mathrm{Na}^{+}$-dependent anion exchanger NDCBE/ SLC4A8 mediates thiazide-sensitive electroneutral $\mathrm{NaCl}$ reabsorption in the CCD. This finding may have important implications tion was reduced by $60 \%$ (Figure $1 \mathrm{~A}$ ). In contrast, luminal addition of $10^{-4} \mathrm{M}$ hydrochlorothiazide (HCTZ) abolished both $\mathrm{J}_{\mathrm{Cl}}$ and the amiloride-insensitive component of $\mathrm{J}_{\mathrm{Na}}$, whereas $\mathrm{J}_{\mathrm{K}}$ and $\mathrm{V}_{\text {te }}$ were not affected by HCTZ (Figure 1A). We next tested the effects of luminal addition of $10^{-4} \mathrm{M} \mathrm{HCTZ}$ on $\mathrm{J}_{\mathrm{Na}}, \mathrm{J}_{\mathrm{Cl}}, \mathrm{J}_{\mathrm{K}}$, and $\mathrm{V}_{\mathrm{te}}$ in the absence of amiloride. Figure $1 \mathrm{~B}$ shows that $\mathrm{HCTZ}$ decreased $\mathrm{Na}^{+}$absorption by approximately $45 \%$ and almost abolished $\mathrm{Cl}^{-}$absorption. However, HCTZ did not affect either $\mathrm{V}_{\text {te }}$ or $\mathrm{K}^{+}$secretion (Figure 1B). Taken together, these results strongly support the hypothesis that HCTZ inhibits a system that is different from $\mathrm{ENaC}$ and that mediates electroneutral $\mathrm{NaCl}$ absorption in the mouse collecting duct.

To further exclude a role for $\mathrm{ENaC}$ in the amiloride-insensitive, HCTZ-sensitive component of sodium reabsorption, we similarly 

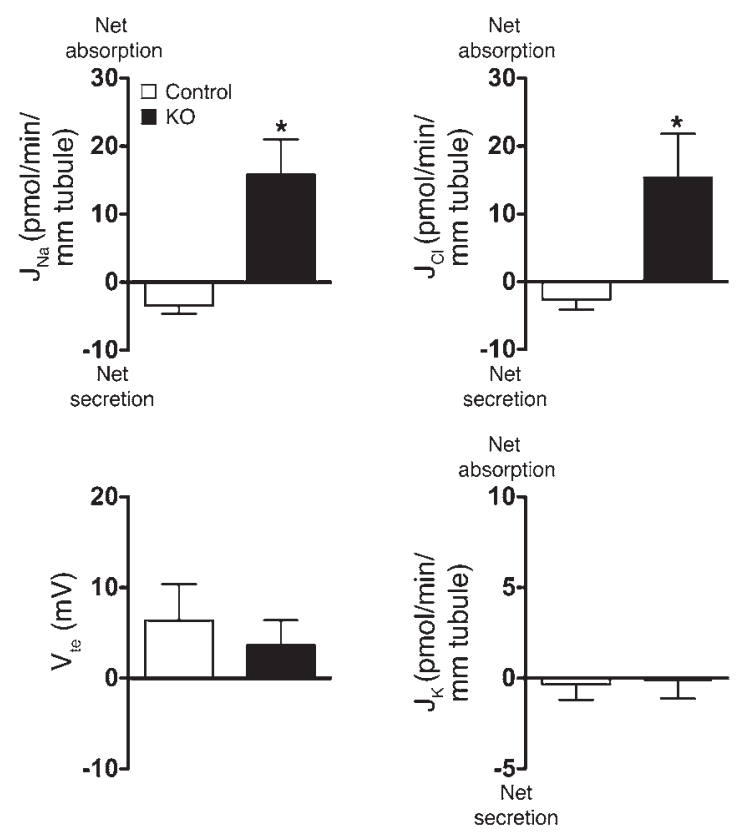

studied isolated perfused CCDs from mice with a collecting ductspecific disruption of $\alpha-\mathrm{ENaC}(22)$ in vitro. It has been shown previously in this genetic model that disruption of the Scnn1a locus in the CCD abolishes $\alpha-E N a C$ protein expression and prevents the apical membrane expression of $\beta$ and $\gamma$ subunits in CCD cells (22), resulting in the complete ablation of ENaC channel activity in the collecting duct (22). As shown in Figure 2, CCDs from control mice on a normal $\mathrm{Na}^{+}$diet again had no significant $\mathrm{Na}^{+}$, $\mathrm{Cl}^{-}$, or $\mathrm{K}^{+}$transport. Importantly, as also shown in Figure 2, CCDs from collecting duct-specific $\mathrm{ENaC}-\mathrm{KO}$ mice on a $\mathrm{Na}^{+}$-depleted diet absorbed $\mathrm{Na}^{+}$and $\mathrm{Cl}^{-}$but did not generate a lumen-negative transepithelial voltage and did not secrete $\mathrm{K}^{+}$. Our results confirm that the thiazide-sensitive component of $\mathrm{Na}^{+}$absorption is $\mathrm{ENaC}$ independent and most likely occurs through an electroneutral mechanism that does not promote $\mathrm{K}^{+}$secretion.

CCDs from NCC-deficient mice display thiazide-sensitive NaCl absorption. To investigate whether the thiazide-sensitive component of $\mathrm{Na}^{+}$absorption in the CCD might occur through NCC, we measured ion transport and $\mathrm{V}_{\text {te }}$ in CCDs from mice with a genetic disruption of Slc12a3, the gene encoding NCC ( $\mathrm{Ncc}^{-/}$mice) (23). Western blot and immunofluorescence analyses confirmed the complete absence of the NCC protein in this mouse model $(24,25)$. CCDs from $\mathrm{Ncc}^{-1-}$ mice on a NaCl-replete diet absorbed $\mathrm{Na}^{+}$and

\section{Figure 2}

Analyses of $\mathrm{J}_{\mathrm{Na}}, \mathrm{J}_{\mathrm{Cl}}$, and $\mathrm{J}_{\mathrm{K}}$ and $\mathrm{V}_{\mathrm{te}}$ in CCDs isolated from collecting duct-specific ENaC-KO mice maintained on a $\mathrm{Na}^{+}$-depleted diet. The control group consists of littermate mice floxed for $\alpha$-ENaC but negative for the HoxB7-Cre transgene, as detailed elsewhere (22). The control group was kept on a normal $\mathrm{Na}^{+}$diet to provide the zero baseline values for each variable. Statistical significance was assessed by 2-tailed unpaired Student's $t$ test. $n=5$ in each group; ${ }^{*} P<0.05$.

$\mathrm{Cl}^{-}$, whereas CCDs from pair-fed wild-type mice did not (Figure 3). Thus, after genetic disruption of Slc12a3, $\mathrm{NaCl}$ absorption was increased in the CCD, presumably consequent to sodium depletion. $\mathrm{NaCl}$ absorption in CCDs from $\mathrm{Ncc}^{-1}$ mice was amiloride insensitive but was fully inhibited by HCTZ (Figure 3). A lumen-negative $\mathrm{V}_{\text {te }}$ or $\mathrm{K}^{+}$secretion in CCDs from $\mathrm{Ncc}^{-/}$mice was never observed in any of the experimental conditions studied (data not shown). Thus, under $\mathrm{NaCl}$-replete conditions, CCDs from mice with a targeted disruption of $\mathrm{Ncc}$ have little $\mathrm{ENaC}$-mediated $\mathrm{Na}^{+}$absorption but have robust electroneutral, thiazide-sensitive $\mathrm{NaCl}$ reabsorption.

To assess the physiological relevance of this transport system, we investigated whether thiazides have a diuretic effect in vivo in the absence of NCC (Figure 4). Consistent with the in vitro studies, we observed significant HCTZ-induced natriuresis and chloriuresis in $\mathrm{Ncc}^{-/}$mice, although the response was smaller and delayed relative to that in $\mathrm{Ncc}^{+/+}$mice (Figure 4). We conclude that NCC-independent thiazide-sensitive sodium absorption participates in renal sodium absorption and regulation of sodium balance in vivo.

Thiazide-sensitive $\mathrm{NaCl}$ absorption in the CCD is bicarbonate dependent and involves 2 ion transporters. In many epithelia, $\mathrm{NaCl}$ transport occurs through a $\mathrm{Cl}^{-} / \mathrm{HCO}_{3}{ }^{-}$and a $\mathrm{Na}^{+} / \mathrm{H}^{+}$exchanger working in parallel. In the $\mathrm{CCD}, \mathrm{Cl}^{-}$absorption is eliminated with genetic ablation of Slc26a4 $(20,26)$, the gene encoding the $\mathrm{Cl}^{-} / \mathrm{HCO}_{3}{ }^{-}$ exchanger pendrin that is found in the apical regions of type $\mathrm{B}$ and non-A-non-B intercalated cells (27). Since $\mathrm{Cl}^{-}$transport in the CCD occurs through pendrin, we hypothesized that HCTZ-sensitive $\mathrm{NaCl}$ transport results from the coupling of pendrin-mediated $\mathrm{Cl}^{-}$reabsorption with $\mathrm{H}^{+} / \mathrm{HCO}_{3}^{-}$-dependent $\mathrm{Na}^{+}$transport. Supporting this hypothesis, removal of $\mathrm{CO}_{2} / \mathrm{HCO}_{3}{ }^{-}$from the perfusion and bath solutions abolished both $\mathrm{Na}^{+}$and $\mathrm{Cl}^{-}$transport by perfused CCDs isolated from $\mathrm{Ncc}^{-1-}$ mice (Figure 5).

To identify the apical sodium transporter, we measured changes in intracellular $\mathrm{pH}\left(\mathrm{pH}_{\mathrm{i}}\right)$ in response to luminal $\mathrm{Na}^{+}$removal and then to luminal $\mathrm{Na}^{+}$readdition. Experiments were performed in the absence of basolateral $\mathrm{Na}^{+}$to silence basolateral $\mathrm{Na}^{+} / \mathrm{H}^{+}$ exchange. Intercalated cells were distinguished from principal cells by their fluorescein-conjugated peanut lectin labeling (28) and by their greater uptake of BCECF when the fluorophore was added

\section{Figure 3}

Effects of amiloride $\left(10^{-5} \mathrm{M}\right)$ and $\mathrm{HCTZ}\left(10^{-4} \mathrm{M}\right)$ on $\mathrm{Na}^{+}$and $\mathrm{Cl}^{-}$transepithelial fluxes in CCDs isolated from $\mathrm{NcC}^{+/+}$and $\mathrm{NCC}^{-/-}$mice fed a $\mathrm{Na}^{+}$-replete diet. Statistical significance was assessed by ANOVA; comparisons between groups were tested by Bonferroni's post-hoc test. $n=5$ in each group; ${ }^{*} P<0.05$ versus $\mathrm{NCC}^{+/+} ;{ }^{\#} P<0.05$ versus $\mathrm{NCC}^{-/-} ;{ }^{\dagger} P<0.05$ versus $\mathrm{NCC}^{-/-}$amil.
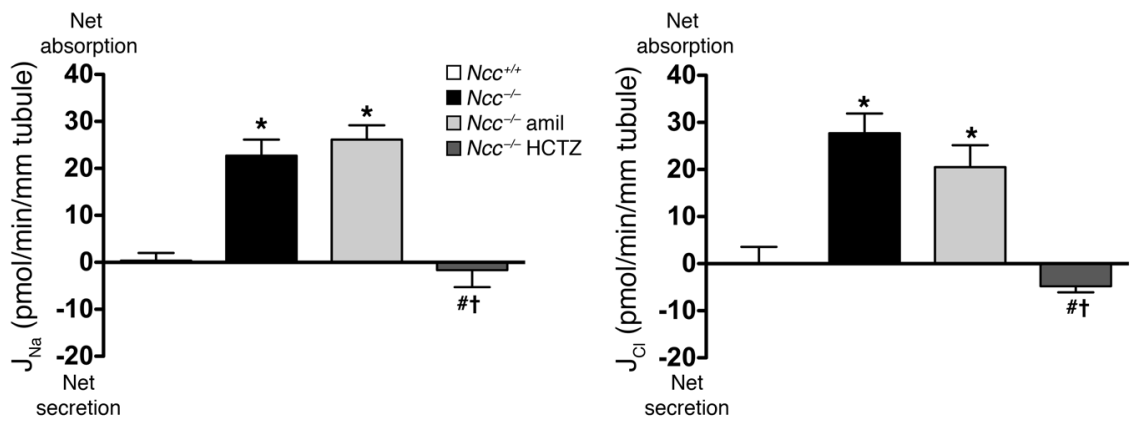

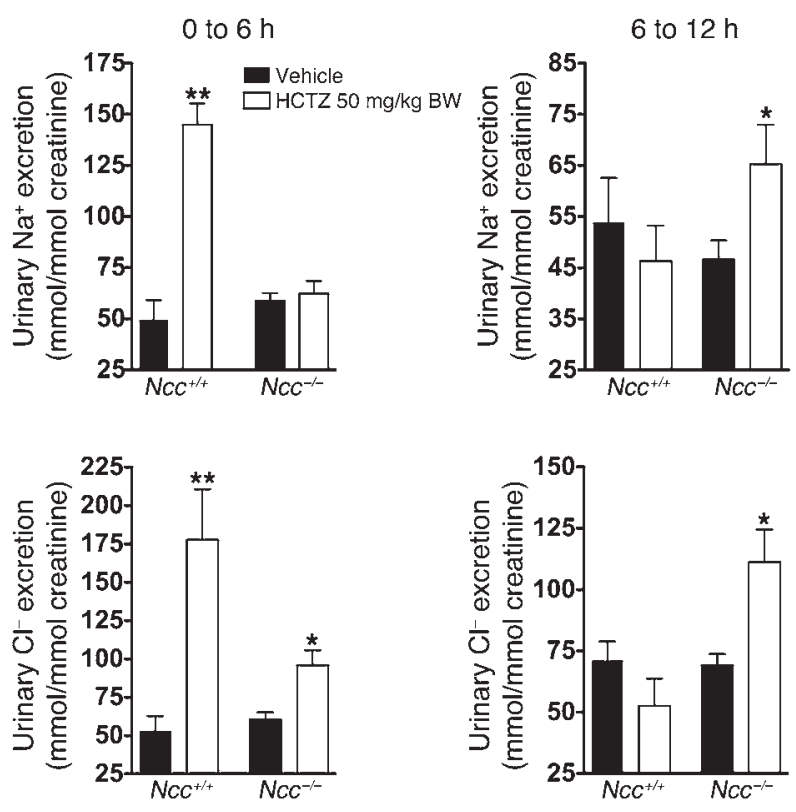

to the perfusate (29). Whereas in CCDs isolated from wild-type mice fed a standard $\mathrm{Na}^{+}$-replete diet, $\mathrm{pH}_{\mathrm{i}}$ in both intercalated and principal cells was insensitive to changes in luminal $\mathrm{Na}^{+}$(data not shown), and intercalated cell $\mathrm{pH}_{\mathrm{i}}$ in CCDs of $\mathrm{Na}^{+}$-depleted wildtype mice fell with removal of $\mathrm{Na}^{+}$from the perfusate. This drop in $\mathrm{pH}_{\mathrm{i}}$ was fully reversed when $\mathrm{Na}^{+}$was reintroduced into the lumen (Figure 6A). These findings indicate the presence of a $\mathrm{Na}^{+}$-coupled acid-base transporter that is upregulated in the apical membrane of intercalated cells in response to a $\mathrm{Na}^{+}$-restricted diet. Furthermore, the activity of this transporter was abolished in the absence of $\mathrm{Cl}^{-}$and greatly reduced in the nominal absence of $\mathrm{CO}_{2} / \mathrm{HCO}_{3}$ (Figure 6A), indicating that sodium uptake is mediated by a $\mathrm{Na}^{+}-$ driven $\mathrm{Cl}^{-} / \mathrm{HCO}_{3}{ }^{-}$exchanger rather than by a $\mathrm{Na}^{+} / \mathrm{H}^{+}$exchanger or a $\mathrm{Na}^{+}-\mathrm{HCO}_{3}{ }^{-}$cotransporter. Because luminal removal of $\mathrm{Na}^{+}$did not elicit any detectable $\mathrm{pH}_{\mathrm{i}}$ changes in principal cells in the CCD (data not shown), this $\mathrm{Na}^{+}$-driven $\mathrm{Cl}^{-} / \mathrm{HCO}_{3}{ }^{-}$exchanger appears to be restricted to intercalated cells.

While many $\mathrm{HCO}_{3}{ }^{-}$transporters have been reported in the mammalian kidney, only NDCBE (encoded by Slc4a8) mediates $\mathrm{Na}^{+}$and $\mathrm{Cl}^{-}$-dependent $\mathrm{HCO}_{3}{ }^{-}$transport $(30,31)$. NDCBE promotes the electroneutral exchange of 1 intracellular $\mathrm{Cl}^{-}$ion for $1 \mathrm{Na}^{+}$and $2 \mathrm{HCO}_{3}{ }^{-}$ions. Although predominantly expressed in the brain and testis, NDCBE is also detected in the kidney, the digestive tract, the retina, the thyroid, the aorta, and the spinal cord (see Supplemental Figure 1A and Supplemental Figure 2; supplemental material available online with this article; doi:10.1172/JCI40145DS1). Slc4a8 transcripts were confirmed in mouse CCDs by RT-PCR (data not shown). Since our preceding experiments suggested that NDCBE might be important for $\mathrm{Na}^{+}$transport by intercalated cells, we genetically disrupted Slc4a8 in mice (Supplemental Figure $1, \mathrm{~B}$ and C). $\mathrm{Ndcbe}^{-/-}$mice produced from heterozygous matings followed Mendelian ratios and had no obvious phenotypical abnormalities. NDCBE protein was detected by immunoblot in renal cortex and isolated CCDs of wild-type mice, but not in $\mathrm{Ndcbe}^{-/-}$mice (Figure 6B).

To determine whether NDCBE participates in amiloride-resistant $\mathrm{NaCl}$ transport in mouse CCDs, we characterized $\mathrm{Na}^{+}$and $\mathrm{Cl}^{-}$

\section{Figure 4}

Effects of HCTZ on urinary excretion of $\mathrm{Na}^{+}$and $\mathrm{Cl}^{-}$in $\mathrm{NcC}^{+/+}$and $\mathrm{NCc}^{-1-}$ mice. One single dose of HCTZ (50 mg/kg body weight) or vehicle was administered intraperitoneally to $\mathrm{NCC}^{+/+}$and $\mathrm{NcC}^{-/-}$mice. Urine samples were collected from 0 to 6 and from 6 to 12 hours after injection to measure urinary $\mathrm{Na}^{+}$(top panels) or $\mathrm{Cl}^{-}$(bottom panels) excretion. Results are expressed as the ratio to urinary creatinine. Statistical significance was assessed by 2-tailed Student's unpaired $t$ test. $n=5$ in WT groups and $n=8$ in KO groups; ${ }^{*} P<0.05$, ${ }^{* *} P<0.01$ versus vehicle.

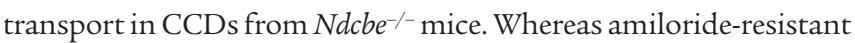
$\mathrm{NaCl}$ absorption was detectable in CCDs from $\mathrm{Na}^{+}$-depleted WT mice, $\mathrm{NaCl}$ absorption in the presence of luminal amiloride was not different from zero in CCDs from $\mathrm{Na}^{+}$depleted $\mathrm{Ndcbe} e^{-/-}$mice, demonstrating that amiloride-resistant $\mathrm{Na}^{+}$transport depends on NDCBE (Figure 6C).

To assess whether HCTZ inhibits amiloride-resistant $\mathrm{NaCl}$ absorption by blocking NDCBE, and/or pendrin, we next tested the effects of $10^{-4} \mathrm{M} \mathrm{HCTZ}$ on $\mathrm{Na}^{+}$-dependent and $\mathrm{Na}^{+}$-independent $\mathrm{Cl}^{-} / \mathrm{HCO}_{3}{ }^{-}$exchange activities. $\mathrm{Na}^{+}$-dependent $\mathrm{pH}$ changes, in the nominal presence of extracellular $\mathrm{Cl}^{-}$and $\mathrm{HCO}_{3}{ }^{-}$, were present in CCDs of $\mathrm{Na}^{+}$-depleted $\mathrm{Ndcbe} e^{+/+}$mice but completely abolished in CCDs of $\mathrm{Na}^{+}$-depleted $\mathrm{Ndcbe}^{-/-}$mice (Figure 7A), confirming the role of NDCBE in mediating this process. In addition, $\mathrm{Na}^{+}$-dependent $\mathrm{pH}_{\mathrm{i}}$ changes were abolished by luminal HCTZ $\left(10^{-4} \mathrm{M}\right)$. Similarly, apical $\mathrm{Cl}^{-} / \mathrm{HCO}_{3}{ }^{-}$exchange mediated by pendrin was abolished by luminal HCTZ (Figure 7B). However, when heterologously expressed in Xenopus oocytes, NDCBE activity was not significantly affected by HCTZ $(0.25 \mathrm{mM})$, and pendrin activity was inhibited by HCTZ (Figure 7C), although inhibition was only partial and required higher $(1 \mathrm{mM})$ HCTZ concentrations than those found to inhibit this process in isolated CCDs. This difference in sensitivity could be due to the very different experimental conditions (e.g., temperature of the assays). However, it is also possible that HCTZ has an additional indirect effect of inhibiting NDCBE or pendrin in native CCDs. As HCTZ does not block NCC exclusively, but also inhibits carbonic anhydrase (32), we next tested the effects of the carbonic anhydrase inhibitor acetazolamide (ACZ) on $\mathrm{J}_{\mathrm{Na}}$ and $\mathrm{J}_{\mathrm{Cl}}$ and on NDCBE and pendrin activities measured in isolated CCDs. While ACZ abolished $\mathrm{Cl}^{-}$absorption (Figure $8 \mathrm{~A}$ ) as well as $\mathrm{Na}^{+}$-independent $\mathrm{Cl}^{-} / \mathrm{HCO}_{3}{ }^{-}$ exchange (i.e., pendrin) activity (Figure 8B), it had no effect on $\mathrm{Na}^{+}$absorption (Figure 8C) or on NDCBE activity (Figure 8D),
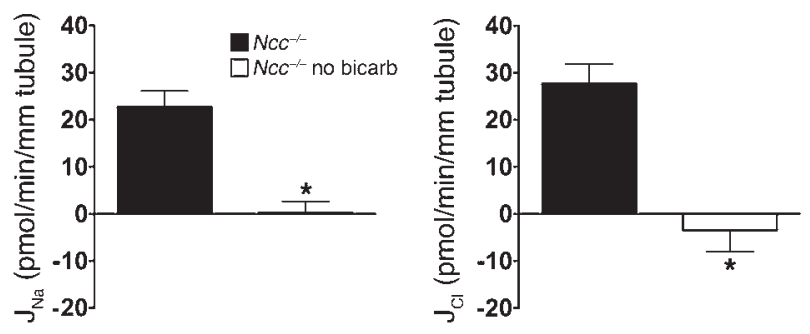

\section{Figure 5}

Effects of bicarbonate on transepithelial fluxes of $\mathrm{Na}^{+}$and $\mathrm{Cl}^{-}$in CCDs isolated from $\mathrm{NcC}^{-/-}$mice. CCDs from $\mathrm{NcC}^{-/-}$mice were either perfused in $\mathrm{CO}_{2} / \mathrm{HCO}_{3}^{-}$-containing solutions or in $\mathrm{CO}_{2} / \mathrm{HCO}_{3}^{-}$-free (no bicarbonate [no bicarb]) buffer. Statistical significance was assessed by 2-tailed Student's unpaired $t$ test. $n=5$ in each group; ${ }^{*} P<0.001$ versus control. 
A $\mathrm{Cl}_{0}^{-}$: present; $\mathrm{HCO}_{3}^{-}:$present
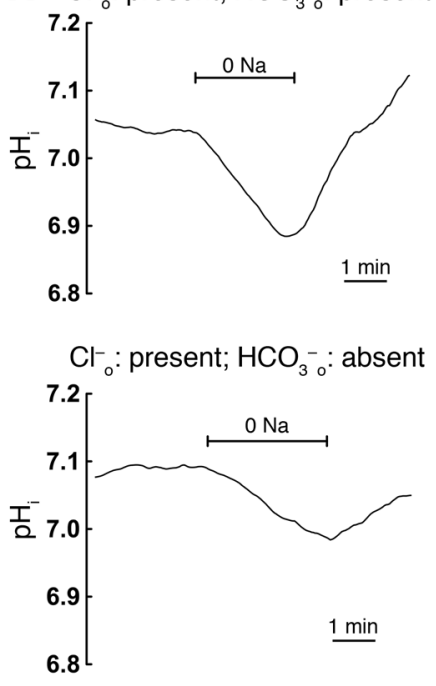
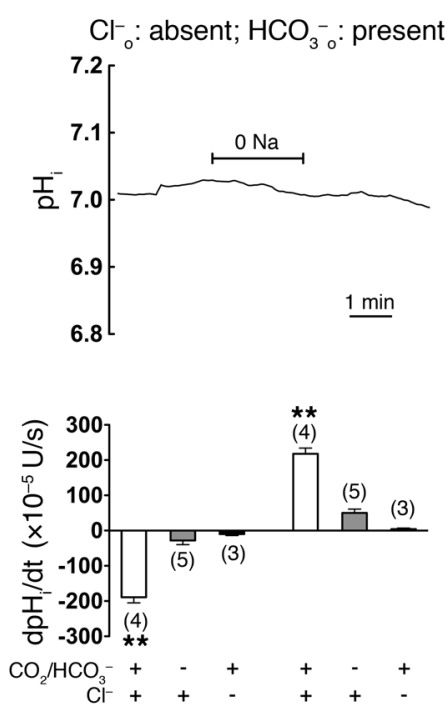

B

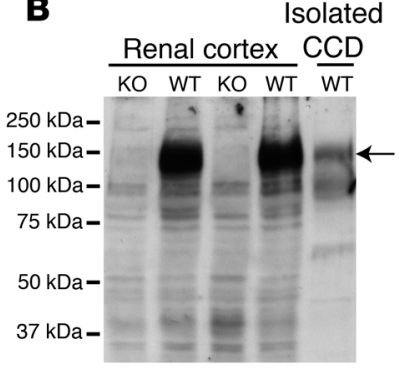

C

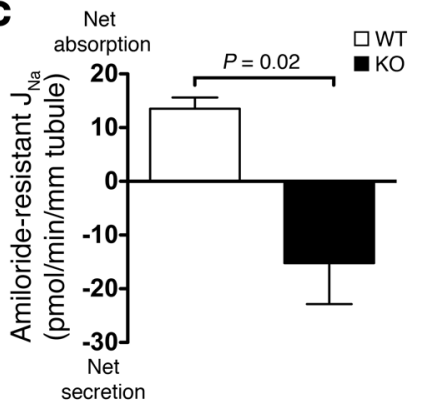

Net

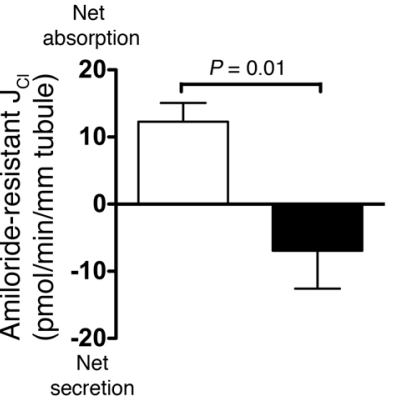

\section{Figure 6}

Detection and functional characterization of NDCBE in collecting ducts isolated from wild-type mice fed a $\mathrm{Na}^{+}$-depleted diet. (A) $\mathrm{Na}^{+}$dependence of $\mathrm{pH}_{\mathrm{i}}$ changes in intercalated cells of CCDs isolated from mice fed a $\mathrm{Na}^{+}$-depleted diet. Traces are the average of $\mathrm{pH}_{\mathrm{i}}$ changes recorded when luminal $\mathrm{Na}^{+}$was removed from, and then readded to the perfusate. Upper-left panel: Both $\mathrm{Cl}^{-}$and $\mathrm{HCO}_{3}{ }^{-} / \mathrm{CO}_{2}$ were present in the extracellular fluid; mean starting $\mathrm{pH}_{\mathrm{i}}$ (immediately before luminal $\mathrm{Na}^{+}$removal) was $7.03 \pm 0.04$. Upper right: extracellular $\mathrm{Cl}^{-}$was absent; mean starting $\mathrm{pH}_{\mathrm{i}}$ was $7.03 \pm 0.05$. Lower left: extracellular $\mathrm{HCO}_{3}{ }^{-}$$\mathrm{CO}_{2}$ was absent; mean starting $\mathrm{pH}_{\mathrm{i}}$ was $7.09 \pm 0.11$. Lower right: initial rates of $\mathrm{pH}_{\mathrm{i}}$ changes during exposure to different solutions. Values are mean \pm SEM, with number of tubules in parentheses. Statistical significance was tested by ANOVA followed by Bonferroni's post-hoc test. ${ }^{* \star} P<0.01$ versus all other groups. 0 , outside. (B) Western blot analyses of NDCBE in the mouse kidney and CCD. Western blot analyses of $50 \mu \mathrm{g}$ membrane fraction proteins from renal cortex isolated from $\mathrm{Ndcbe}^{-/}$mice or wild-type mice or of proteins from 100 CCDs (corresponding to $\sim 25 \mathrm{~mm}$ of tubule) isolated from wild-type mice. NDCBE was detected in the renal cortex or isolated tubules of wild-type but not of $\mathrm{Ndcbe}^{-/-}$mice. Note that the apparent difference in abundance of NDCBE between the lane loaded with total cortex and the one loaded with isolated CCD does not reflect an enrichment of the cortex versus the CCD, but actually only reflects the difference in the quantity of protein loaded. (C) Analyses of amiloride-resistant $\mathrm{Na}^{+}$and $\mathrm{Cl}^{-}$transepithelial fluxes in CCDs isolated from NDCBE-KO mice maintained on a $\mathrm{Na}^{+}$-depleted diet. Fluxes were measured in the presence of $10^{-5} \mathrm{M}$ amiloride in the perfusate to reflect only the amiloride-resistant, HCTZ-sensitive component of $\mathrm{NaCl}$ reabsorption. Values are mean $\pm \mathrm{SEM}$; statistical significance was assessed by unpaired Student's $t$ test with Welch's correction, when appropriate. $n=5$ in each group. which excludes the possibility that HCTZ affects $\mathrm{Na}^{+}$transport through its effect on carbonic anhydrase.

Taken together, these data confirm that HCTZ inhibits NDCBE and pendrin in the intact tubule and thereby amiloride-resistant electroneutral $\mathrm{NaCl}$ absorption in the CCD.

\section{Discussion}

Only two apical sodium transporters are established in the distal nephron where aldosterone modulates sodium, potassium, and acid-base homeostasis: the thiazide-sensitive cotransporter $\mathrm{NCC}$ (4), which mediates electroneutral $\mathrm{NaCl}$ cotransport, and the amiloride-sensitive sodium channel $\mathrm{ENaC}(5)$, which mediates electrogenic $\mathrm{Na}^{+}$absorption (Recently, the $\mathrm{Na}^{+}-\mathrm{HCO}_{3}{ }^{-}$cotransporter NBCn1/Slc4a7 has also been shown to be present in the collecting duct [refs. 33, 34]. However, no evidence has been reported yet that $\mathrm{NBCn} 1$ participates in transepithelial $\mathrm{Na}^{+}$absorption.)
Except at the very end of the DCT (or DCT2), there is no overlap of expression of the 2 proteins, as NCC is restricted to the DCT and $\mathrm{ENaC}$ to principal cells of the connecting tubule and collecting duct, respectively (35). Here, we identified what we believe to be a new mechanism of apical $\mathrm{NaCl}$ uptake in the collecting duct that results from parallel operation of 2 bicarbonate transporters: the $\mathrm{Na}^{+}$driven $\mathrm{Cl}^{-} / \mathrm{HCO}_{3}{ }^{-}$exchanger $\mathrm{NDCBE}$ and the $\mathrm{Na}^{+}$-independent anion exchanger pendrin. In vivo and in isolated tubules, this mechanism mediates net electroneutral thiazide-sensitive $\mathrm{NaCl}$ reabsorption in the CCD, thereby exhibiting an "NCC-like" activity. Our findings explain why thiazides block $50 \%$ of sodium absorption in rat CCD (17-19), although NCC was repeatedly shown to be absent from this nephron segment in different species (36-39). Moreover, the demonstration of thiazide-sensitive $\mathrm{NaCl}$ absorption in mice with genetic ablation of NCC (Figure 3) definitively rules out a possible involvement of the latter in this 

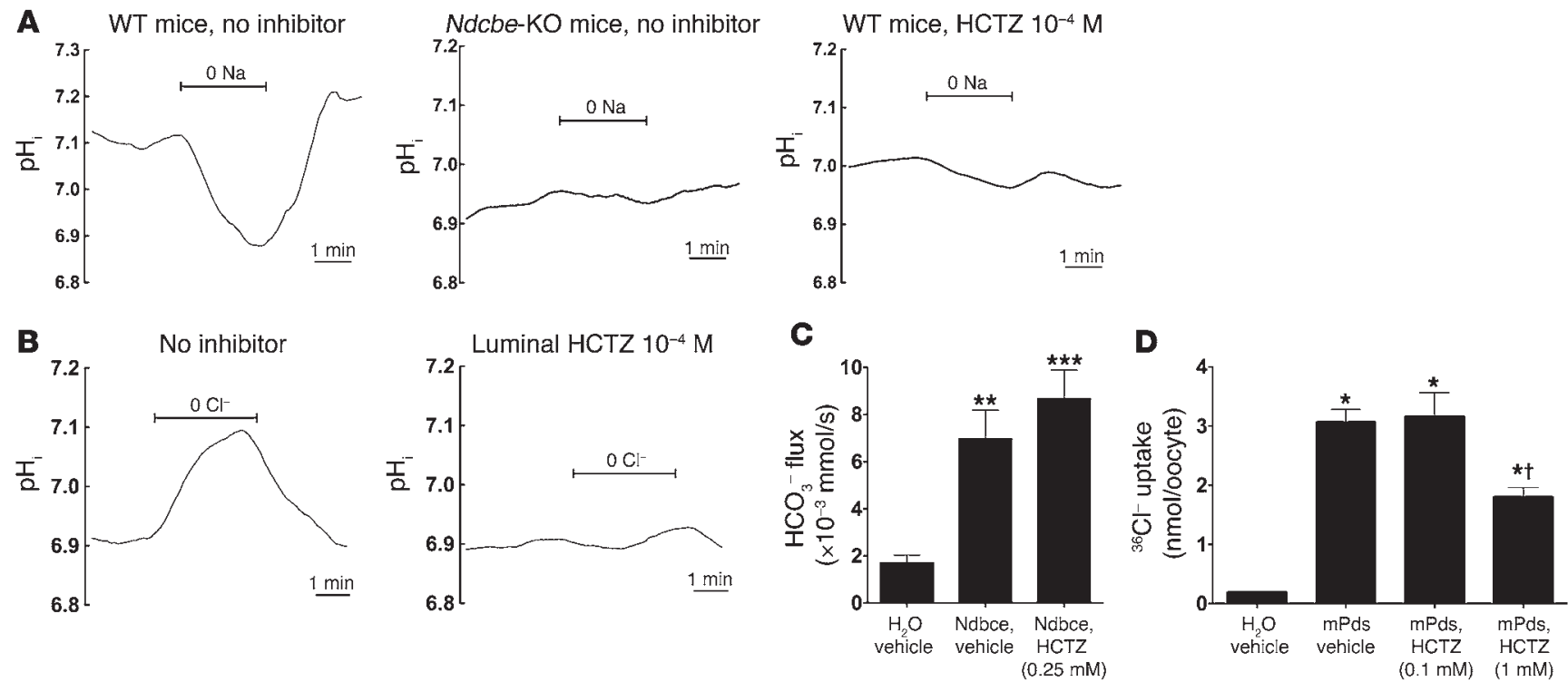

\section{Figure 7}

Effects of HCTZ $\left(10^{-4} \mathrm{M}\right)$ on NDCBE or PDS activity in isolated collecting ducts or on recombinant NDCBE or PDS expressed in Xenopus oocytes. (A) Effects of HCTZ and $\mathrm{Ndcb}$ e disruption on $\mathrm{Na}^{+}$-dependent $\mathrm{pH}_{\mathrm{i}}$ changes measured in intercalated cells of CCD isolated from Nadepleted $\mathrm{Ndcbe}^{-/-}$or $\mathrm{Ndcbe}^{+/+}$mice fed a low-Na+ diet. Traces are the average of $\mathrm{pH}_{\mathrm{i}}$ changes recorded when luminal $\mathrm{Na}^{+}$was removed and then readded, in the presence of extracellular $\mathrm{Cl}^{-}(122 \mathrm{mM})$ and $\mathrm{HCO}_{3}{ }^{-}(25 \mathrm{mM})$. Intracellular $\mathrm{Na}^{+}$-dependent acidification was detected in $\mathrm{Ndcbe}^{+/+}$ mice but absent in $\mathrm{Ndcbe}^{-/-}$mice or when HCTZ $10^{-4} \mathrm{M}$ was present in the perfusate. In these 3 different experimental conditions, mean starting $\mathrm{pH}_{\mathrm{i}}$ values were $7.10 \pm 0.02,6.93 \pm 0.11$, and $7.01 \pm 0.04$, respectively. (B) Effects of $\mathrm{HCTZ}$ on apical $\mathrm{Cl}^{-} / \mathrm{HCO}_{3}{ }^{-}$exchange activity in intercalated cells of CCDs isolated from Na-depleted animals. Traces are the average of $\mathrm{pH}_{\mathrm{i}}$ changes recorded when luminal $\mathrm{Cl}^{-}$was removed and then readded, in the presence of extracellular $\mathrm{HCO}_{3}{ }^{-}(25 \mathrm{mM})$ and in $\mathrm{Na}^{+}$-free solutions. Intracellular $\mathrm{Cl}^{-}$-dependent alkalinization, reflecting apical $\mathrm{Cl}-/ \mathrm{HCO}_{3}{ }^{-}$exchange, was completely abolished when $10^{-4} \mathrm{M} \mathrm{HCTZ}$ was present in the perfusate. Mean starting $\mathrm{pH}$ ivalues (immediately before $\mathrm{Cl}^{-}$removal) were $6.91 \pm 0.03$ and $6.89 \pm 0.08$, in the absence and presence of $\mathrm{HCTZ}$, respectively. (C) Effects of $\mathrm{HCTZ}$ on mNdcbe-mediated $\mathrm{HCO}_{3}{ }^{-}$influx. Oocytes had been injected with $\mathrm{mNdcbe} \mathrm{cRNA}$ or $\mathrm{H}_{2} \mathrm{O}$ and incubated with $\mathrm{HCTZ}(0.25 \mathrm{mM})$. As a control, NDCBE-expressing and $\mathrm{H}_{2} \mathrm{O}$-injected oocytes were incubated with vehicle (methanol). Values are mean $\pm \mathrm{SEM}$ with $6-9$ oocytes per group. ${ }^{* *} P<0.01$, ${ }^{* * *} P<0.001$ versus $\mathrm{H}_{2} \mathrm{O}$-injected oocyte. $\mathrm{HCO}_{3}{ }^{-}$flux was unaffected by the application of $\mathrm{HCTZ}(0.25 \mathrm{mM})$ compared with vehicle alone $(P=0.279)$. (D) Effects of HCTZ on Pds-mediated ${ }^{36} \mathrm{Cl}^{-}$uptake. Pendrin-expressing oocytes (mPds) were incubated in ND96 containing 0.1 or $1 \mathrm{mM} \mathrm{HCTZ} \mathrm{during} \mathrm{the}$ uptake period (16 minutes). As a control, pendrin-expressing and $\mathrm{H}_{2} \mathrm{O}$-injected oocytes were incubated with vehicle (methanol). Values are mean \pm SEM, with 6-16 oocytes per group. ${ }^{*} P<0.001$ versus $\mathrm{H}_{2} \mathrm{O} ;{ }^{\dagger} P<0.001$ versus $\mathrm{mPds}, \mathrm{HCTZ} 0.1 \mathrm{mM}$.

process. It is likely that the $\mathrm{Na}^{+}$reabsorption pathway we describe here plays a relevant role in the regulation of sodium balance, since it is stimulated in response to either dietary sodium restriction (Figure 1) or renal salt wasting upon disruption of NCC (Figure 3); moreover, its inhibition by $\mathrm{HCTZ}$ increases $\mathrm{Na}^{+}$and $\mathrm{Cl}^{-}$excretion in NCC-deficient mice (Figure 4). Thus, our data imply that the anti-hypertensive action of thiazides might be, at least partially, mediated by inhibition of sodium transport in the CCD and not exclusively in the DCT. The observations that mice with impaired expression of $\mathrm{ENaC}$ all along the distal nephron exhibit marked renal salt wasting, mimicking pseudohypoaldosteronism type I (PHA1) (40), whereas mice with collecting duct-specific ablation of $\mathrm{ENaC}$ maintain sodium balance even when challenged with a low-sodium diet (22), have suggested that the collecting duct does not importantly participate in the regulation of extracellular volume, since increased $\mathrm{ENaC}$ activity and expression in the late DCT and the CNT are able to fully compensate for ENaC deletion in the $\operatorname{CCD}(22,41)$. However, the present finding that collecting ducts isolated from these mice exhibit net electroneutral $\mathrm{NaCl}$ absorption after sodium deprivation also supports the concept that $\mathrm{ENaC}$ is not the only important mechanism responsible for adaptive changes of sodium absorption in the collecting duct.
Indeed, based on our results, it is possible that NDCBE/pendrin might also represent part of the compensatory mechanism. Nevertheless, the observation that complete $\mathrm{ENaC}$ deletion leads to PHA1 indicates that electroneutral $\mathrm{NaCl}$ absorption through the intercalated cells cannot fully replace $\mathrm{ENaC}$-mediated $\mathrm{Na}^{+}$absorption but rather plays a complementary role.

Within the distal nephron, sodium transport is important not only for sodium balance regulation but also for potassium and acid-base homeostasis. In fact, sodium absorption through $\mathrm{ENaC}$ in principal cells is electrogenic and generates a lumen-negative transepithelial voltage (Figure 1), which in turn stimulates $\mathrm{K}^{+}$and $\mathrm{H}^{+}$secretion. The importance of this mechanism is highlighted by the features of primary hyperaldosteronism, or Conn syndrome, in which the excess of aldosterone, the main hormone stimulating $\mathrm{ENaC}$, promotes sodium retention and arterial hypertension together with renal hypokalemia and metabolic alkalosis. Conversely, blockade of $\mathrm{ENaC}$, for example, by amiloride-related diuretics, leads to hyperkalemia and metabolic acidosis. However, under certain circumstances, such as dietary sodium restriction, which also stimulates aldosterone secretion, sodium balance is maintained by an increase in distal nephron sodium absorption without any alteration of $\mathrm{K}^{+}$or $\mathrm{H}^{+}$homeostasis (42). This phenom- 
A
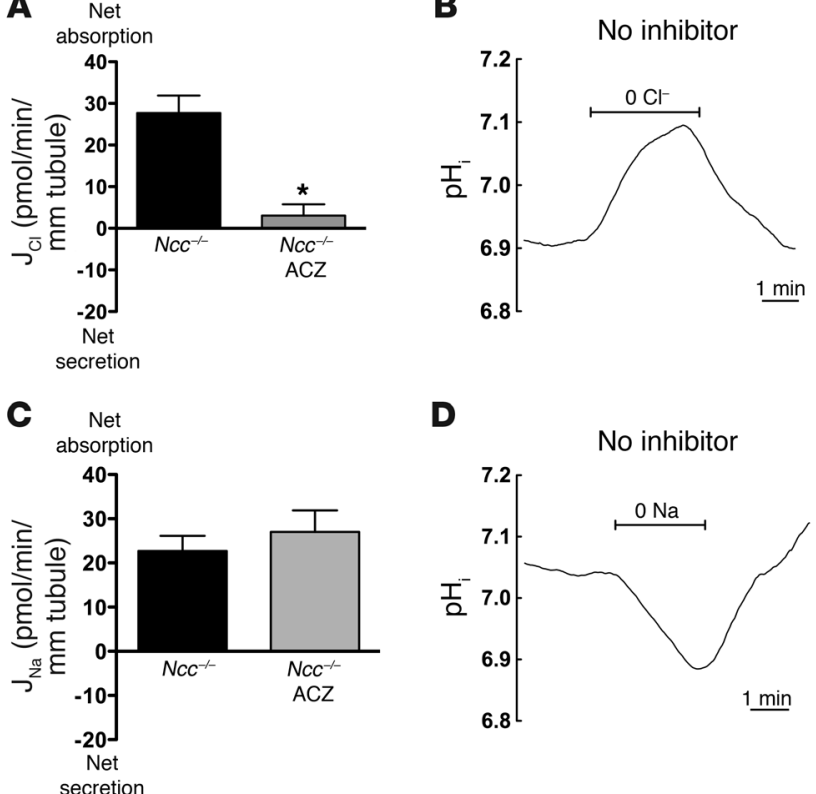

D

B
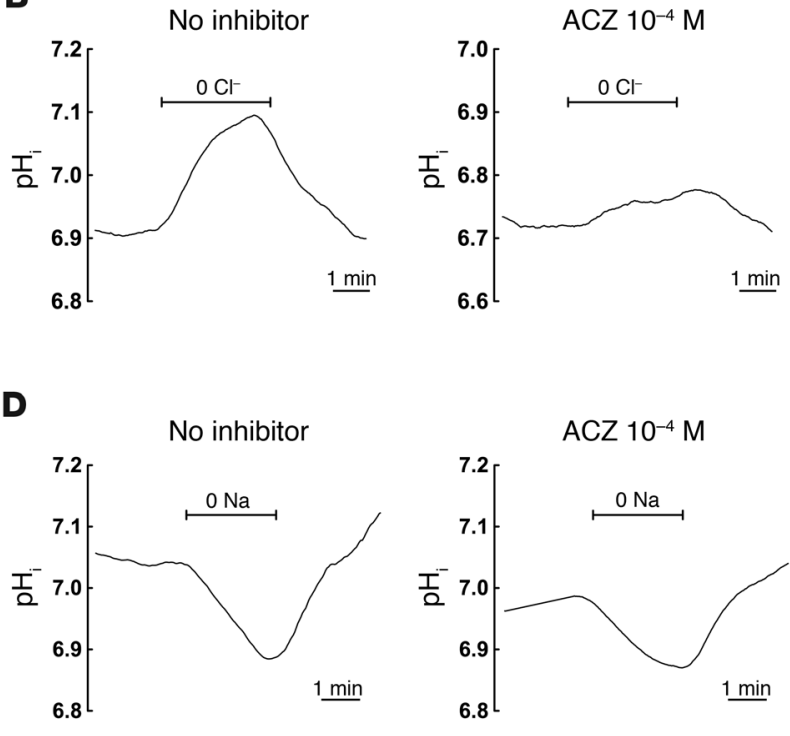

Figure 8

Effects of ACZ (10-4 M) on NDCBE- or PDS-dependent transport in isolated collecting ducts. (A) Effects of $10^{-4} \mathrm{M} \mathrm{ACZ}$ on $\mathrm{Cl}^{-}$transepithelial transport in CCDs isolated from $\mathrm{NcC}^{-/-}$mice. CCDs were isolated from $\mathrm{NcC}^{-/-}$mice and bathed and perfused with $\mathrm{CO}_{2} / \mathrm{HCO}_{3}{ }^{-}$-containing solutions. Statistical significance was assessed by 2-tailed Student's unpaired $t$ test. $n=5$ in each group; ${ }^{\star} P<0.001$ versus control. (B) Effects of luminal $10^{-4} \mathrm{M} \mathrm{ACZ}$ on pendrin activity in isolated CCDs. Tubules were isolated from wild-type mice. Pendrin activity was assessed by measuring changes in $\mathrm{pH}_{\mathrm{i}}$ when $\mathrm{Cl}^{-}$was removed and then readded from the perfusate. Both bath and perfusate solutions contained $25 \mathrm{mM} \mathrm{HCO}_{3}{ }^{-}$and were sodium-free. Traces represent the average of recordings from independent tubules. $n=4-5$ independent tubules by group. Mean starting $\mathrm{pH}_{\mathrm{i}}$ values were $6.91 \pm 0.03$ and $6.72 \pm 0.05$, in the absence and presence of ACZ, respectively. (C) Effects of luminal $10^{-4} \mathrm{M} \mathrm{ACZ}$ on $\mathrm{Na}^{+}$transepithelial transport in CCDs isolated from $\mathrm{NcC}^{-/}$mice. Statistical significance was assessed by 2-tailed Student's unpaired $t$ test. $n=5$ in each group. (D) Effects of ACZ 10-4 M on NDCBE activity in isolated CCDs. Tubules were isolated from wild-type mice. NDCBE activity was assessed by measuring changes in $\mathrm{pH}_{\mathrm{i}}$ of intercalated cells when $\mathrm{Na}^{+}$was removed and then readded from the perfusate. Both bath and perfusate solutions contained $25 \mathrm{mM} \mathrm{HCO}_{3}{ }^{-}$and $122 \mathrm{mM} \mathrm{Cl}^{-}$. The bath solution was sodium-free to silence basolateral $\mathrm{Na}^{+} / \mathrm{H}^{+}$exchanger activity. Traces represent the average of recordings from independent tubules. $n=4-5$ independent tubules by group. Mean starting $\mathrm{pH}_{\mathrm{i}}$ values were $7.03 \pm 0.04$ and $6.99 \pm 0.05$, in the absence and presence of $A C Z$, respectively.

enon, known as the "aldosterone paradox," implies that, depending on the needs of the organism, the kidney is able to increase distal nephron sodium absorption with or without promoting $\mathrm{K}^{+}$ or $\mathrm{H}^{+}$secretion. Recently, it was shown that the balance between electroneutral $\mathrm{NaCl}$ absorption by NCC within the DCT and electrogenic $\mathrm{Na}^{+} / \mathrm{K}^{+}\left(\mathrm{H}^{+}\right)$"exchange" promoted by $\mathrm{ENaC}$ in the connecting tubule and the collecting duct is finely tuned by the WNK pathway $(43,44)$. Our finding that the collecting duct also performs electroneutral $\mathrm{NaCl}$ absorption suggests that this balance might also occur within the CCD: The relative contribution of $\mathrm{ENaC}$ and pendrin/NDCBE to $\mathrm{NaCl}$ absorption in the CCD determines the magnitude of the transepithelial voltage in the CCD and thereby modulates $\mathrm{K}^{+}$and $\mathrm{H}^{+}$secretion. In the different situations studied here, electroneutral $\mathrm{NaCl}$ accounted for $40 \%-100 \%$ of total transepithelial $\mathrm{Na}^{+}$absorption. In $\mathrm{Ncc}^{-/-}$mice, a model in which upregulation of $\mathrm{ENaC}$ is thought to promote $\mathrm{K}^{+}$wasting (45), we observed that electroneutral $\mathrm{NaCl}$ transport was the dominant mechanism accounting for sodium absorption in the collecting duct. This suggests that $\mathrm{Ncc}^{1-}$ mice, by favoring this electroneutral
pKO-V901 plasmid (Lexicon Genetics) with a phosphoglycerate kinase (pgk) promoter-driven diphtheria toxin A cassette. A pgk promoter-driven neomycin resistance cassette flanked by loxP sites was inserted into the MfeI site in intron 11. A third loxP site and an additional EcoRI site were inserted into the KpnI site in intron 12. The construct was electroporated into R1 mouse embryonic stem cells. Neomycin-resistant clones were analyzed by Southern blot using EcoRI and an external approximately 500-bp probe. Correctly targeted ES cells were transfected with a plasmid expressing Cre-recombinase to remove the neomycin cassette and exon 12 . Correctly recombined clones were identified with an internal second probe by Southern blot analysis after $E c o$ RI digestion. Two independent embryonic stem cell clones were injected into C57BL/6 blastocysts to generate chimeras that were backcrossed with C57BL/6 mice. Studies were performed in a mixed 129Sv/ C57BL/ 6 background in the $\mathrm{F}_{6}$ and $\mathrm{F}_{7}$ generation. Genotypes were determined either by Southern blot or by PCR of tail biopsy DNA. For PCR genotyping, the sense primers F1 (5'-GGCTAGGCAGTTCTTATCTTTCCC-3'), F2 (5'-GAGCAGCCCAGATGTACACCAGC- $\left.3^{\prime}\right)$ and the antisense primers R1 (5'-GGCAATCCCCGTCATGGACG-3') were used in a single PCR mix. The primer pair F1/R1 amplified a 320-bp wild-type allele, and the primer 
pair F2/R1 a 423-bp KO allele. Southern and Northern blot analyses were performed as described in ref. 46 .

Antibody generation and Western blot analysis. The NDCBE antiserum was raised in rabbits against the epitope ALSINSGNTKEKSPFN (amino acids 1,074-1,089, accession number NP_067505) and affinity purified. For Western blot analyses, 10-60 $\mu \mathrm{g}$ of the membrane-enriched protein fraction was separated on reducing 7.5\% SDS-polyacrylamide gels. Blots were probed with the rabbit NDCBE antibody at a dilution of 1:250. Detection was done with the chemiluminescence ECL kit (Amersham Biosciences).

In vitro microperfusion, transepithelial ion fluxes, and $\mathrm{pH}$ measurements. CCD segments were isolated from corticomedullary rays under a dissecting microscope with a sharpened forceps. Because CCDs are highly heterogeneous, relatively short segments $(0.45-0.6 \mathrm{~mm})$ were dissected to maximize the reproducibility of the isolation procedure. In vitro microperfusion was performed as described by Burg et al. (47). Because CCDs from mice are frequently unstable and collapse rapidly, measurements were conducted during the first 90 minutes of perfusion. Usually, collections from 4 periods of 15 minutes were performed in which $15-20 \mathrm{nl}$ of fluid were collected. The volume of the collections was determined under water-saturated mineral oil with calibrated volumetric pipettes. For $\left[\mathrm{Na}^{+}\right],\left[\mathrm{K}^{+}\right]$, and [creatinine] measurements, 11-15 $\mathrm{nl}$ were required, while 2-3 nanoliters were used for $\left[\mathrm{Cl}^{-}\right]$determinations. Transepithelial voltage $\left(\mathrm{V}_{\mathrm{te}}\right)$ was measured continuously between $\mathrm{Ag}-\mathrm{AgCl}$ electrodes connected to 0.15 - $\mathrm{M} \mathrm{NaCl}$-agar bridges inserted in the perfusion pipette and bathing solutions. Values for each period were averaged.

Intracellular $\mathrm{pH}$ was monitored using the $\mathrm{pH}$-sensitive dye BCECF (29). Intracellular dye was calibrated at the end of each experiment using the high- $\left[\mathrm{K}^{+}\right] /$nigericin technique (48). Briefly, tubules were perfused and bathed with a HEPES-buffered, $95-\mathrm{mM} \mathrm{K}^{+}$solution containing $10 \mu \mathrm{M}$ of the $\mathrm{K}^{+} / \mathrm{H}^{+}$exchanger nigericin. Four different calibration solutions, titrated to $6.5,6.9,7.3$, or 7.5 , were used. $V_{\text {te }}$ was measured continuously as described elsewhere (49). $\left[\mathrm{Na}^{+}\right],\left[\mathrm{K}^{+}\right]$, and [creatinine] measurements were performed by HPLC (50). $\left[\mathrm{Cl}^{-}\right]$was measured by microcoulometry $(51)$. For each collection, ion flux $(J)$ was calculated and reported to the length of the tubule: $J_{\mathrm{Na}}=$ $\left[\left([\mathrm{Na}]_{\text {perf }} \times \mathrm{V}_{\text {perf }}\right)-\left([\mathrm{Na}]_{\text {coll }} \times \mathrm{V}_{\text {coll }}\right)\right] / 1 ; J_{\mathrm{K}}=\left[\left([\mathrm{K}]_{\text {perf }} \times \mathrm{V}_{\text {perf }}\right)-\left([\mathrm{K}]_{\text {coll }} \times \mathrm{V}_{\text {coll }}\right)\right] / 1$; and $J_{\mathrm{Cl}}=\left[\left([\mathrm{Cl}]_{\text {perf }} \times \mathrm{V}_{\text {perf }}\right)-\left([\mathrm{Cl}]_{\text {coll }} \times \mathrm{V}_{\text {coll }}\right)\right] / 1$, where "perf" indicates perfusate and "coll" indicates collection fluid.Therefore, positive values indicate net absorption, whereas negative values indicate net secretion of the ion. For each tubule, the mean of the 4 collection periods was used.

Measurement of pendrin and NDCBE activities in Xenopus oocytes. Full-length mouse pendrin and NDCBE cDNAs were cloned by PCR from isolated CCDs using the mouse pendrin-specific primers forward 5'-GTCATCCCTCGTCGCATC-3' and reverse 5'-TCTCAGGAAGCAAGTCTACGC-3'; and the mouse NDCBE-specific primers forward $5^{\prime}$-CGCGGATCCGCCACCATGCCCGCCGGGAGCAA-3' and reverse 5'-GCTCTAGATCAGTTGAAGGGGCTTTTTTCTTTTGTATTTCCGG-3'. Both PCR products were subsequently ligated into pGH19 (52) and linearized with XhoI. cRNAs were transcribed using T7 RNA polymerase (mMESSAGE mMACHINE), and their quality was assessed by spectroscopy and agarose gel electrophoresis.

Pendrin activity was assessed as pendrin-dependent ${ }^{36} \mathrm{Cl}$ uptake. Oocytes were prepared from Xenopus laevis as described previously (52). Briefly, stage V-VI oocytes were injected with $25 \mathrm{ng}$ of pendrin cRNA and kept at $16-18^{\circ} \mathrm{C}$ in $\mathrm{ND} 96$ (in mM: $96.0 \mathrm{NaCl}, 2.0 \mathrm{KCl}, 1.0 \mathrm{CaCl}_{2}, 1.8 \mathrm{MgCl}_{2}$, 5.0 HEPES, pH 7.4; supplemented with $5 \mathrm{mM}$ sodium pyruvate and $50 \mathrm{U} / \mathrm{ml}$ penicillin/streptomycin) for 48 hours before measuring ${ }^{36} \mathrm{Cl}$ uptake. Oocytes were washed twice at room temperature in $1 \mathrm{ml}$ chloridefree buffer (in mM: 98 potassium-gluconate, 1.8 hemi-calcium-gluconate,
1 hemi-magnesium-gluconate, 5 Tris-HEPES, $\mathrm{pH} 7.5$ ) and then incubated in $500 \mu \mathrm{l}$ uptake medium (in mM: 100 potassium-gluconate, 5 Tris, $\mathrm{pH}$ adjusted to 7.5 with HEPES) containing $1.74 \mathrm{mM}{ }^{36} \mathrm{Cl}$ for 16 minutes. The oocytes were then washed 3 times in ice-cold chloride-free buffer and subsequently lysed individually in $200 \mu \mathrm{l}$ of $10 \%$ SDS. The radioisotope content of each individual oocyte was measured by scintillation spectrometry after adding $3 \mathrm{ml}$ scintillation fluid (Opti-Fluor, Packard).

NDCBE activity was assessed as NDCBE-dependent bicarbonate influx as described previously (31). Oocytes were injected with either $25 \mathrm{ng}$ of mNDCBE cRNA or with $\mathrm{H}_{2} \mathrm{O}$ for controls and incubated for 6 days at $18^{\circ} \mathrm{C}$ in OR3 medium (Leibovitz's L15 medium diluted to approximately $200 \mathrm{mOsm} / \mathrm{kg} \mathrm{H}_{2} \mathrm{O}$ ) supplemented with penicillin and streptomycin. The day of assay, oocytes were incubated for approximately 5 hours in ND96 containing either $0.5 \%$ methanol (vehicle) or ND96 containing $0.25 \mathrm{mM}$ HCTZ $/ 0.5 \%$ methanol. The $\mathrm{pH}_{\mathrm{i}}$ of the oocytes was monitored as the cells were perfused with a solution containing $5 \% \mathrm{CO}_{2} / 33 \mathrm{mM} \mathrm{HCO}_{3}{ }^{-}$in the continued presence of HCTZ and/or vehicle. The measurement of $\mathrm{pH}_{\mathrm{i}}$ using a $\mathrm{H}^{+}$-selective microelectrode has been described in detail elsewhere (53). Briefly, each oocyte is placed in a plastic perfusion chamber and impaled with a $\mathrm{H}^{+}$-selective microelectrode and a $\mathrm{KCl}$-filled reference electrode. The cell is first perfused with ND96 solution until a stable $\mathrm{pH}_{\mathrm{i}}$ reading is obtained, then the perfusion system is switched to deliver a $5 \%$ $\mathrm{CO}_{2} / 33 \mathrm{mM} \mathrm{HCO}{ }^{-}$-containing solution. An initial $\mathrm{CO}_{2}$-induced acid load was followed by a $\mathrm{pH}_{\mathrm{i}}$ increase that was converted - using the calculated buffering power of each oocyte - into a measure of " $\mathrm{HCO}_{3}{ }^{-}$flux" into the cells. Data are acquired using an FD223 dual-channel differential electrometer and analyzed using in-house software. $\mathrm{HCO}_{3}{ }^{-}$influx data (rates of $\mathrm{pH}_{\mathrm{i}}$ increase) are converted into $\mathrm{HCO}_{3}{ }^{-}$flux $(\mathrm{mM} / \mathrm{s})$ using the calculated buffering power of the oocyte (change in $\mathrm{pH}_{\mathrm{i}}$ due to entry of $\mathrm{CO}_{2}$ plus the open-system buffering power due to $\mathrm{HCO}_{3}{ }^{-}$).

Statistics. Experimental results are summarized as mean \pm SEM. All statistical comparisons were made by use of unpaired Student's $t$ test or by ANOVA followed by a Bonferroni's post-hoc test when appropriate. A $P$ value less than 0.05 was considered significant.

\section{Acknowledgments}

Dominique Eladari and coworkers are funded by the Institut National de La Santé et de la Recherche Médicale (INSERM), by the Transatlantic Network on Hypertension from the Fondation Leducq, and by grant PHYSIO 2007-RPV07084 to D. Eladari from l'Agence Nationale de la Recherche (ANR); Christian A. Huebner and coworkers are funded by the Deutsche Forschungsgemeinschaft (grant HU 800/3-1 and HU 800/2-1 to C.A. Hübner), and Susan Wall is funded by the National Institute of Diabetes and Digestive and Kidney Diseases (grant DK 52935).

Received for publication June 10, 2009, and accepted in revised form February 3, 2010.

Address correspondence to: Dominique Eladari, INSERM U872, Equipe 3, 15 rue de l'Ecole de Médecine, Esc. E RDC, F-75006, Paris, France. Phone: 33.144413718; Fax: 33.144413717; E-mail: dominique.eladari@crc.jussieu.fr.

Hassan Hatim's present address is: University of Chicago, Section of Nephrology, Department of Medicine, Chicago, Illinois, USA.
1. Guyton AC. Blood pressure control - special role of the kidneys and body fluids. Science. 1991; 252(5014):1813-1816.

2. Tse CM, Brant SR, Walker MS, Pouyssegur J, Donow- itz $\mathrm{M}$. Cloning and sequencing of a rabbit cDNA encoding an intestinal and kidney-specific $\mathrm{Na}^{+} /$ $\mathrm{H}+$ exchanger isoform (NHE-3). J Biol Chem. 1992; 267(13):9340-9346.
3. Gamba G, et al. Molecular cloning, primary structure, and characterization of two members of the mammalian electroneutral sodium-(potassium)chloride cotransporter family expressed in kidney. 
J Biol Chem. 1994;269(26):17713-17722.

4. Gamba G, et al. Primary structure and functional expression of a cDNA encoding the thiazide-sensitive, electroneutral sodium-chloride cotransporter. Proc Natl Acad Sci U S A. 1993;90(7):2749-2753.

5. Canessa CM, et al. Amiloride-sensitive epithelial $\mathrm{Na}+$ channel is made of three homologous subunits. Nature. 1994;367(6462):463-467.

6. Chang SS, et al. Mutations in subunits of the epithelial sodium channel cause salt wasting with hyperkalaemic acidosis, pseudohypoaldosteronism type 1. Nat Genet. 1996;12(3):248-253.

7. Schultheis PJ, et al. Renal and intestinal absorptive defects in mice lacking the NHE3 $\mathrm{Na}+/ \mathrm{H}+$ exchanger. Nat Genet. 1998;19(3):282-285.

8. Simon DB, Karet FE, Hamdan JM, DiPietro A, Sanjad SA, Lifton RP. Bartter's syndrome, hypokalaemic alkalosis with hypercalciuria, is caused by mutations in the $\mathrm{Na}-\mathrm{K}-2 \mathrm{Cl}$ cotransporter NKCC2. Nat Genet. 1996;13(2):183-188.

9. Simon DB, et al. Gitelman's variant of Bartter's syndrome, inherited hypokalaemic alkalosis, is caused by mutations in the thiazide-sensitive $\mathrm{Na}$ Cl cotransporter. Nat Genet. 1996;12(1):24-30.

10. Ji W, et al. Rare independent mutations in renal salt handling genes contribute to blood pressure variation. Nat Genet. 2008;40(5):592-599.

11. Lifton RP, Gharavi AG, Geller DS. Molecular mechanisms of human hypertension. Cell. 2001; 104(4):545-556.

12. Beyer KH Jr, Baer JE, Russo HF, Noll R. Electrolyte excretion as influenced by chlorothiazide. Science. 1958;127(3290):146-147.

13. Chobanian AV, et al. The seventh report of the joint national committee on prevention, detection, evaluation, and treatment of high blood pressure: the JNC 7 report. JAMA. 2003;289(19):2560-2572.

14. ALLHAT Officers and Coordinators for the ALLHAT Collaborative Research Group. Major outcomes in high-risk hypertensive patients randomized to angiotensin-converting enzyme inhibitor or calcium channel blocker vs diuretic: The Antihypertensive and Lipid-Lowering Treatment to Prevent Heart Attack Trial (ALLHAT). JAMA. 2002; 288(23):2981-2997.

15. Velazquez H, Wright FS. Effects of diuretic drugs on $\mathrm{Na}, \mathrm{Cl}$, and $\mathrm{K}$ transport by rat renal distal tubule. Am J Physiol. 1986;250(6 Pt 2):F1013-F1023.

16. Greger R. Physiology of renal sodium transport. Am J Med Sci. 2000;319(1):51-62.

17. Terada Y, Knepper MA. Thiazide-sensitive $\mathrm{NaCl}$ absorption in rat cortical collecting duct. $A m \mathrm{~J}$ Physiol. 1990;259(3 Pt 2):F519-F528.

18. Tomita K, Pisano JJ, Burg MB, Knepper MA. Effects of vasopressin and bradykinin on anion transport by the rat cortical collecting duct. Evidence for an electroneutral sodium chloride transport pathway. J Clin Invest. 1986;77(1):136-141.

19. Tomita K, Pisano JJ, Knepper MA. Control of sodium and potassium transport in the cortical collecting duct of the rat. Effects of bradykinin, vasopressin, and deoxycorticosterone. J Clin Invest. 1985; 76(1):132-136.

20. Pech V, Kim YH, Weinstein AM, Everett LA, Pham
TD, Wall SM. Angiotensin II increases chloride absorption in the cortical collecting duct in mice through a pendrin-dependent mechanism. Am J Physiol Renal Physiol. 2007;292(3):F914-F920.

21. Garty H, Palmer LG. Epithelial sodium channels: function, structure, and regulation. Physiol Rev. 1997; 77(2):359-396.

22. Rubera I, et al. Collecting duct-specific gene inactivation of alphaENaC in the mouse kidney does not impair sodium and potassium balance. JClin Invest. 2003;112(4):554-565.

23. Schultheis PJ, et al. Phenotype resembling Gitelman's syndrome in mice lacking the apical $\mathrm{Na}^{+-} \mathrm{Cl}-$ cotransporter of the distal convoluted tubule. J Biol Chem. 1998;273(44):29150-29155.

24. Brooks HL, et al. Profiling of renal tubule $\mathrm{Na}+$ transporter abundances in NHE3 and NCC null mice using targeted proteomics. J Physiol. 2001; 530(Pt 3):359-366.

25. Loffing J, et al. Altered renal distal tubule structure and renal $\mathrm{Na}(+)$ and $\mathrm{Ca}(2+)$ handling in a mouse model for Gitelman's syndrome. J Am Soc Nephrol. 2004;15(9):2276-2288

26. Wall SM, et al. $\mathrm{NaCl}$ restriction upregulates renal Slc26a4 through subcellular redistribution: role in Cl- conservation. Hypertension. 2004;44(6):982-987.

27. Royaux IE, et al. Pendrin, encoded by the Pendred syndrome gene, resides in the apical region of renal intercalated cells and mediates bicarbonate secretion. Proc Natl Acad Sci U S A. 2001;98(7):4221-4226.

28. LeHir M, Kaissling B, Koeppen BM, Wade JB. Binding of peanut lectin to specific epithelial cell types in kidney. Am J Physiol. 1982;242(1):C117-C120.

29. Weiner ID, Hamm LL. Use of fluorescent dye BCECF to measure intracellular $\mathrm{pH}$ in cortical collecting tubule. Am J Physiol. 1989;256(5 Pt 2):F957-F964.

30. Parker MD, Musa-Aziz R, Rojas JD, Choi I, Daly CM, Boron WF. Characterization of human SLC4A10 as an electroneutral $\mathrm{Na} / \mathrm{HCO} 3$ cotransporter $(\mathrm{NBCn} 2)$ with Cl- self-exchange activity. J Biol Chem. 2008; 283(19):12777-12788

31. Grichtchenko II, et al. Cloning, characterization, and chromosomal mapping of a human electroneutral $\mathrm{Na}(+)$-driven $\mathrm{Cl}-\mathrm{HCO} 3$ exchanger. $J$ Biol Chem. 2001;276(11):8358-8363.

32. Beyer KH, Baer JE. Physiological basis for the action of newer diuretic agents. Pharmacol Rev. 1961; 13:517-562.

33. Boedtkjer E, Praetorius J, Fuchtbauer EM, Aalkjaer C. Antibody-independent localization of the electroneutral $\mathrm{Na}+-\mathrm{HCO} 3-$ cotransporter NBCn1 (slc4a7) in mice. Am J Physiol Cell Physiol. 2008; 294(2):C591-C603.

34. Pushkin A, et al. NBC3 expression in rabbit collecting duct: colocalization with vacuolar $\mathrm{H}+$-ATPase. Am J Physiol. 1999;277(6 Pt 2):F974-F981.

35. Loffing J, Kaissling B. Sodium and calcium transport pathways along the mammalian distal nephron: from rabbit to human. Am J Physiol Renal Physiol. 2003;284(4):F628-F643.

36. Bachmann S, Velazquez H, Obermuller N, Reilly RF, Moser D, Ellison DH. Expression of the thiazide-sensitive $\mathrm{Na}-\mathrm{Cl}$ cotransporter by rabbit distal convoluted tubule cells. JClin Invest. 1995;96(5):2510-2514.
37. Obermuller N, et al. Expression of the thiazidesensitive $\mathrm{Na}-\mathrm{Cl}$ cotransporter in rat and human kidney. Am J Physiol. 1995;269(6 Pt 2):F900-F910.

38. Loffing J, et al. Distribution of transcellular calcium and sodium transport pathways along mouse distal nephron. Am J Physiol Renal Physiol. 2001; 281(6):F1021-F1027.

39. Plotkin MD, et al. Localization of the thiazide sensitive $\mathrm{Na}-\mathrm{Cl}$ cotransporter, $\mathrm{rTSC} 1$ in the rat kidney. Kidney Int. 1996;50(1):174-183.

40. Pradervand S, et al. Salt restriction induces pseudohypoaldosteronism type 1 in mice expressing low levels of the beta-subunit of the amiloride-sensitive epithelial sodium channel. Proc Natl Acad Sci US A. 1999;96(4):1732-1737.

41. Meneton P, Loffing J, Warnock DG. Sodium and potassium handling by the aldosterone-sensitive distal nephron: the pivotal role of the distal and connecting tubule. Am J Physiol Renal Physiol. 2004; 287(4):F593-F601.

42. Coffman TM. A WNK in the kidney controls blood pressure. Nat Genet. 2006;38(10):1105-1106.

43. Kahle KT, et al. WNK4 regulates the balance between renal $\mathrm{NaCl}$ reabsorption and $\mathrm{K}+$ secretion. Nat Genet. 2003;35(4):372-376.

44. Lalioti MD, et al. Wnk4 controls blood pressure and potassium homeostasis via regulation of mass and activity of the distal convoluted tubule. Nat Genet. 2006;38(10):1124-1132.

45. Morris RG, Hoorn EJ, Knepper MA. Hypokalemia in a mouse model of Gitelman's syndrome. Am J Physiol Renal Physiol. 2006;290(6):F1416-F1420.

46. Jacobs S, et al. Mice with targeted Slc4a10 gene disruption have small brain ventricles and show reduced neuronal excitability. Proc Natl Acad Sci U S A. 2008; 105(1):311-316.

47. Burg M, Grantham J, Abramow M, Orloff J. Preparation and study of fragments of single rabbit nephrons. Am J Physiol. 1966;210(6):1293-1298.

48. Bourgeois S, Masse S, Paillard M, Houillier P. Basolateral membrane $\mathrm{Cl}(-)-, \mathrm{Na}(+)$-, and $\mathrm{K}(+)$-coupled base transport mechanisms in rat MTALH. Am J Physiol Renal Physiol. 2002;282(4):F655-F668.

49. Lerolle N, Bourgeois S, Leviel F, Lebrun G, Paillard $\mathrm{M}$, Houillier P. Angiotensin II inhibits $\mathrm{NaCl}$ absorption in the rat medullary thick ascending limb. Am J Physiol Renal Physiol. 2004;287(3):F404-F410.

50. Di Stefano A, Jounier S, Wittner M. Evidence supporting a role for $\mathrm{KCl}$ cotransporter in the thick ascending limb of Henle's loop. Kidney Int. 2001; 60(5):1809-1823.

51. Ramsay JA, Brown RHJ, Croghan PC. Electrometric titration of chloride in small volumes.JExp Biol. 1955; 32:822-829.

52. Knauf F, Yang CL, Thomson RB, Mentone SA, Giebisch G, Aronson PS. Identification of a chloride-formate exchanger expressed on the brush border membrane of renal proximal tubule cells. Proc Natl Acad Sci U S A. 2001;98(16):9425-9430.

53. Toye AM, et al. The human NBCe1-A mutant $\mathrm{R} 881 \mathrm{C}$, associated with proximal renal tubular acidosis, retains function but is mistargeted in polarized renal epithelia. Am J Physiol Cell Physiol. 2006; 291(4):C788-C801. 